\title{
Correlating DYFI Data With Seismic Microzonation in the Region of Montreal
}

\author{
Philippe Rosset $^{1}$, Allison L. Bent ${ }^{2} \&$ Luc E. Chouinard ${ }^{1}$ \\ ${ }^{1}$ Department of Civil Engineering and Applied Mechanics, McGill University, Montreal, Canada \\ ${ }^{2}$ Natural Resources Canada, Ottawa, Canada \\ Correspondence: Philippe Rosset, Department of Civil Engineering and Applied Mechanics, McGill University \\ Montreal, QC, H3A 0C3, Canada. E-mail: philippe.rosset@mail.mcgill.ca
}

Received: July 14, 2020

Accepted: July 30, 2020

Online Published: July 31, 2020

doi:10.5539/esr.v9n2p85

URL: https://doi.org/10.5539/esr.v9n2p85

\begin{abstract}
The Western Quebec seismic zone has moderate seismic activity with few historical damaging earthquakes. Nevertheless, recent risk analyses have shown that the combination of a high level of urbanization with soft soil deposits in the metropolitan area of Montreal could lead to significant damage and economic losses. Over the two decades, several projects have been completed to develop a seismic microzonation to identify zones where seismic waves could be amplified. During the same period, Natural Resources Canada developed an internet application to collect reports from the population after an earthquake and to convert them to the Modified Mercalli Intensity scale (MMI). This paper presents a first comparison of the MMI data compiled after eight recent earthquakes felt in Montreal area with the existing zonation in terms of soil classes. It shows that the MMI from individual reports increases when the observer is located in a soft soil zone. Statistics on average MMI over a regular grid confirms this trend. The numerous reports collected through the internet application, and future applications based on data collected from social media, could become a very useful source of information to complement seismic field measurements when developing and validating seismic microzonation maps.
\end{abstract}

Keywords: earthquakes, Montreal, DYFI, intensity reports, site effects

\section{Introduction}

Macroseismic mapping based on felt reports was first used to estimate the extent of fault rupture and the distribution of damage after large earthquakes worldwide. The development of instrumented measurements of ground motions and of seismic networks has relegated macroseismology to a secondary role due to the significant time and effort required for its collection, treatment and analysis (Cecic \& Musson, 2004). Newly developed tools and web applications to collect felt information provided by individuals have been useful to improve the use of this type of information. Over the last two decades, the "Did You Feel It" system (acronym DYFI) developed by Wald et al. (1999) has been extensively deployed by seismological services worldwide. Canada made its first foray into collecting intensity data via the internet in 1997, with the 6 November 1997 Cap-Rouge, Quebec earthquake providing the first significant test of the system (Cajka \& Halchuk, 1998). At that time, an internet questionnaire, which was a replica of an older form sent to postmasters following felt earthquakes, was posted to the web after the occurrence of an earthquake of interest and left in place for about a month. Responses were read and a Modified Mercalli Intensity (MMI) was manually assigned to each. By the time of the occurrence of the Val-des-Bois, Quebec, earthquake on 23 June 2010 the system had evolved to an automated one closely resembling and based on that described by Wald et al. (1999) (Halchuk, 2010). Once a report on an earthquake has been posted, submitted DYFI reports may be linked directly to that earthquake. The DYFI questionnaire, however, is permanently available online in both English and French (English and French links) allowing the public to submit felt information prior to the posting of a report for a significant earthquake and also for smaller earthquakes that may receive less attention.

In eastern Canada, the Western Quebec seismic zone has a moderate level of seismic activity where damaging earthquakes are rare. Nevertheless, the maximum predicted level of ground motion based on seismic hazard assessments is large enough to cause damage and economic losses in large urban areas such as the Greater Montreal area (Rosset, Kert, Youance, Nollet, \& Chouinard, 2019; Yu, Rosset, \& Chouinard, 2016). The influence of local soil conditions on the propagation and amplification of seismic waves, especially the marine (Leda) clay of the old Champlain sea, has been extensively studied for the Montreal island and surrounding municipalities (Rosset \& Chouinard, 2009). As a 
result, a seismic microzonation map has been developed, which characterizes soil conditions in terms of predominant frequency of resonance and average shear wave velocity for the first $30 \mathrm{~m}$ of soil. The microzonation map is derived by combining information from seismic measurements and borehole data (Rosset, Bour, \& Chouinard, 2015). The maps have been used to obtain Shakemap scenarios (Ghofrani, Atkinson, Chouinard, Rosset, \& Tiampo, 2015) but has never been validated since no significantly large and close earthquake occurred in recent times and also because the seismic network in this region is very limited in number and quality of stations.

After 23 years of DYFI data collection, the number of available reports for the urban area of Montreal is large enough for a comparison and correlation with the site microzonation. This article presents the spatial distribution of data collected over this period and a statistical comparison between the spatial distribution of the MMI data and soil classes from the microzonation.

\section{Intensity Reports in the Region of Montreal}

Eight earthquakes with a significant number of felt reports in the region of Montreal are used in this study (Table 1). For the seven most recent events, data is obtained from the automatic DYFI system (Earthquakes Canada, 2020), while the felt data from the 1988 M5.9 Saguenay earthquake is obtained from the paper reports compiled by Drysdale and Cajka (1989).

Table 1. Parameters of the recent events felt in the region of Montreal (Earthquakes Canada 2020)

\begin{tabular}{lccccccc}
\hline $\begin{array}{l}\text { Location of the } \\
\text { epicenter }\end{array}$ & Date & Local Time & Lat $\left(^{\circ}\right)$ & Lon $\left(^{\circ}\right)$ & $\begin{array}{l}\text { Depth } \\
(\mathrm{km})\end{array}$ & $\mathrm{M}_{\mathrm{N}}$ & Mw \\
\hline Saguenay & $1988-11-25$ & $23: 46: 04$ & 48.12 & -71.18 & 28 & & 5.9 \\
\hline Sorel-Tracy & $2002-02-11$ & $11: 41: 36$ & 46.06 & -73.45 & 10 & 3.8 & \\
\hline Plattsburgh & $2002-04-20$ & $10: 50: 00$ & 44.53 & -73.73 & 18 & 5.5 & 5.0 \\
\hline Val des Bois & $2010-06-23$ & $17: 41: 41$ & 45.91 & -75.49 & 22.1 & 5.8 & 5.0 \\
\hline Montreal & $2012-10-10$ & $04: 19: 28$ & 45.69 & -73.20 & 21 & 4.5 & 3.9 \\
\hline Gatineau & $2012-11-06$ & $09: 05: 28$ & 45.68 & -74.79 & 15 & 4.2 & 3.5 \\
\hline Ladysmith & $2013-05-17$ & $13: 43: 23$ & 45.73 & -76.34 & 20 & 5.2 & 4.5 \\
\hline Montreal & $2020-03-06$ & $08: 22: 00$ & 45.62 & -73.51 & 12 & 3.3 & \\
\hline
\end{tabular}

Note. Lat=Latitude; Lon=Longitude; $\mathrm{M}_{\mathrm{N}}$ is the Canadian Nuttli magnitude

The map of Figure 1 shows the location of the eight earthquake epicenters as well as Modified Mercalli Intensity (MMI) of the felt reports for all earthquakes. The region of analysis is shown as a rectangle and overlaps with seismic microzonation of Rosset et al. (2015) and the main urbanized areas of the Greater Montreal. 


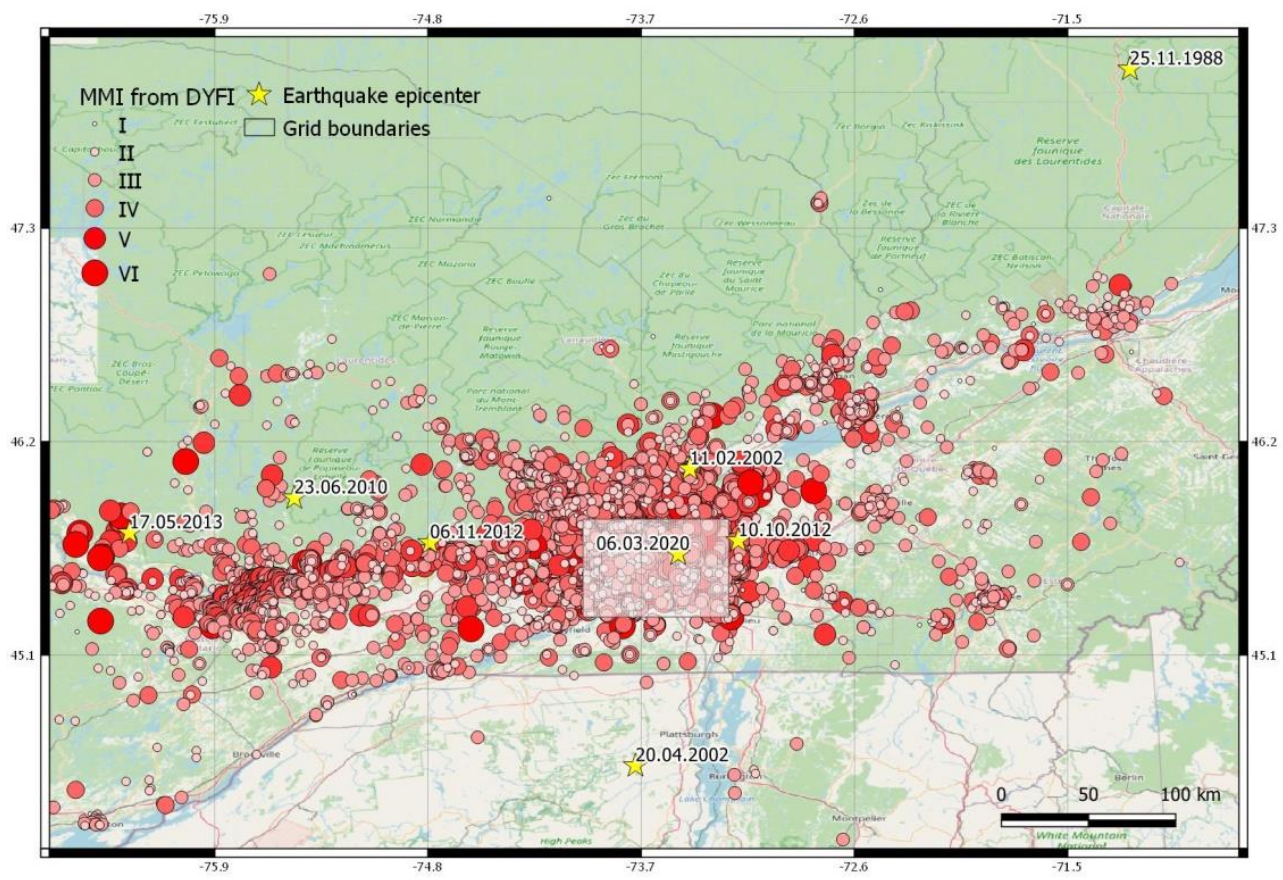

Figure 1. Felt reports data from DYFI in terms of MMI for the eight recent earthquakes around Montreal. Earthquake epicentres are located by yellow stars. The rectangle is the selected region to analyze the MMI data

The MMI data within the selected region (rectangle in the Figure 1) are extracted for each individual earthquake. Shortest distances of the grid from the hypocenter vary from 21 to $356 \mathrm{~km}$. Table 2 provides the distribution of the MMI for different ranges (defined as MMI $=\mathrm{x}$ for the $\mathrm{x} \pm 0.5$ ). MMIs of $\mathrm{V}$ and VI represent less than $10 \%$ of the total number of reports. Most of the reports are for MMIs of III and IV, for example, these represent $87 \%$ of the report for the 2002 event (epicentre at approximately $115 \mathrm{~km}$ south of the grid). MMIs of I and II represent one third of the total number of reports, with no report for the 2002 event and $81 \%$ of the reports for the 2013 event, located at $215 \mathrm{~km}$ from the region of analysis. The more distant event of 1988 located $340 \mathrm{~km}$ eastward exhibits a relatively homogeneous distribution of MMIs up to IV. The relatively high level of ground motion at this large distance has been attributed to the high frequency content of the event (Atkinson \& Boore, 2006) and by directivity effects (Haddon, 1992). There is no clear or statistically significant relation between hypocentral distances and intensity values.

Table 2. Distribution of MMI values for the eight significant felt events in Montreal

\begin{tabular}{|c|c|c|c|c|c|c|c|c|c|c|}
\hline \multirow{2}{*}{ Event } & \multirow{2}{*}{ Magnitude } & \multirow{2}{*}{ Lat. } & \multirow{2}{*}{ Long. } & \multirow{2}{*}{$\begin{array}{l}\text { Hypocentral } \\
\text { distance } \\
(\mathrm{km})\end{array}$} & \multirow{2}{*}{$\begin{array}{l}\text { Number } \\
\text { of } \\
\text { reports }\end{array}$} & \multicolumn{5}{|c|}{ Percentage of reports by MMI level } \\
\hline & & & & & & I-II & III & IV & $\mathrm{V}$ & VI \\
\hline $1988 / 11 / 25$ & M5.9 & 48.12 & -71.18 & $327-356$ & 535 & $31 \%$ & $41 \%$ & $26 \%$ & $3 \%$ & \\
\hline 2002/04/20 & M5.0 & 44.53 & -73.73 & $101-133$ & 319 & & $9 \%$ & $87 \%$ & $4 \%$ & \\
\hline $2010 / 06 / 23$ & M5.0 & 45.90 & -75.50 & $130-160$ & 267 & $42 \%$ & $40 \%$ & $13 \%$ & $2 \%$ & \\
\hline 2012/10/10 & $\mathrm{M}_{\mathrm{N}} 4.5$ & 45.69 & -73.20 & $26-76$ & 7509 & $21 \%$ & $37 \%$ & $34 \%$ & $7 \%$ & $1 \%$ \\
\hline 2012/11/06 & M3.9 & 45.62 & -75.03 & $118-188$ & 764 & $44 \%$ & $49 \%$ & $6 \%$ & & \\
\hline 2013/05/17 & M4.5 & 45.73 & -76.34 & $184-242$ & 123 & $81 \%$ & $18 \%$ & $2 \%$ & & \\
\hline 2020/03/06 & $\mathrm{M}_{\mathrm{N}} 3.3$ & 45.62 & -73.51 & $21-50$ & 1103 & $47 \%$ & $31 \%$ & $19 \%$ & $2 \%$ & \\
\hline \multicolumn{5}{|c|}{ All earthquakes } & 10609 & $27 \%$ & $36 \%$ & $30 \%$ & $6 \%$ & $1 \%$ \\
\hline
\end{tabular}

Note. Lat=Latitude; Lon=Longitude; $\mathrm{M}_{\mathrm{N}}$ is the Canadian Nuttli magnitude; $\mathrm{M}$ is the Moment Magnitude 


\section{Comparison of MMI Reports and Seismic Microzonation}

The distribution of intensity data derived from the eight earthquakes is compared to the seismic microzonation map proposed for the selected region. For this purpose, a rectangular regular grid of $1 \mathrm{~km}$ by $1 \mathrm{~km}$ is overlaid across the seismic microzonation (Rosset et al., 2015; Rosset \& Chouinard, 2009).

The closest events to Montreal are the October 2012 and March 2020 events, with distances varying from 20 to $80 \mathrm{~km}$. The map of the Figure 2 shows the geographic distribution of the felt reports in terms of MMI for the 2020 event superimposed with the seismic microzonation in terms of soil classes. The soil classification is given by the National Building Code of Canada (NBCC, 2015) from A, hard rock to E, very soft soil.

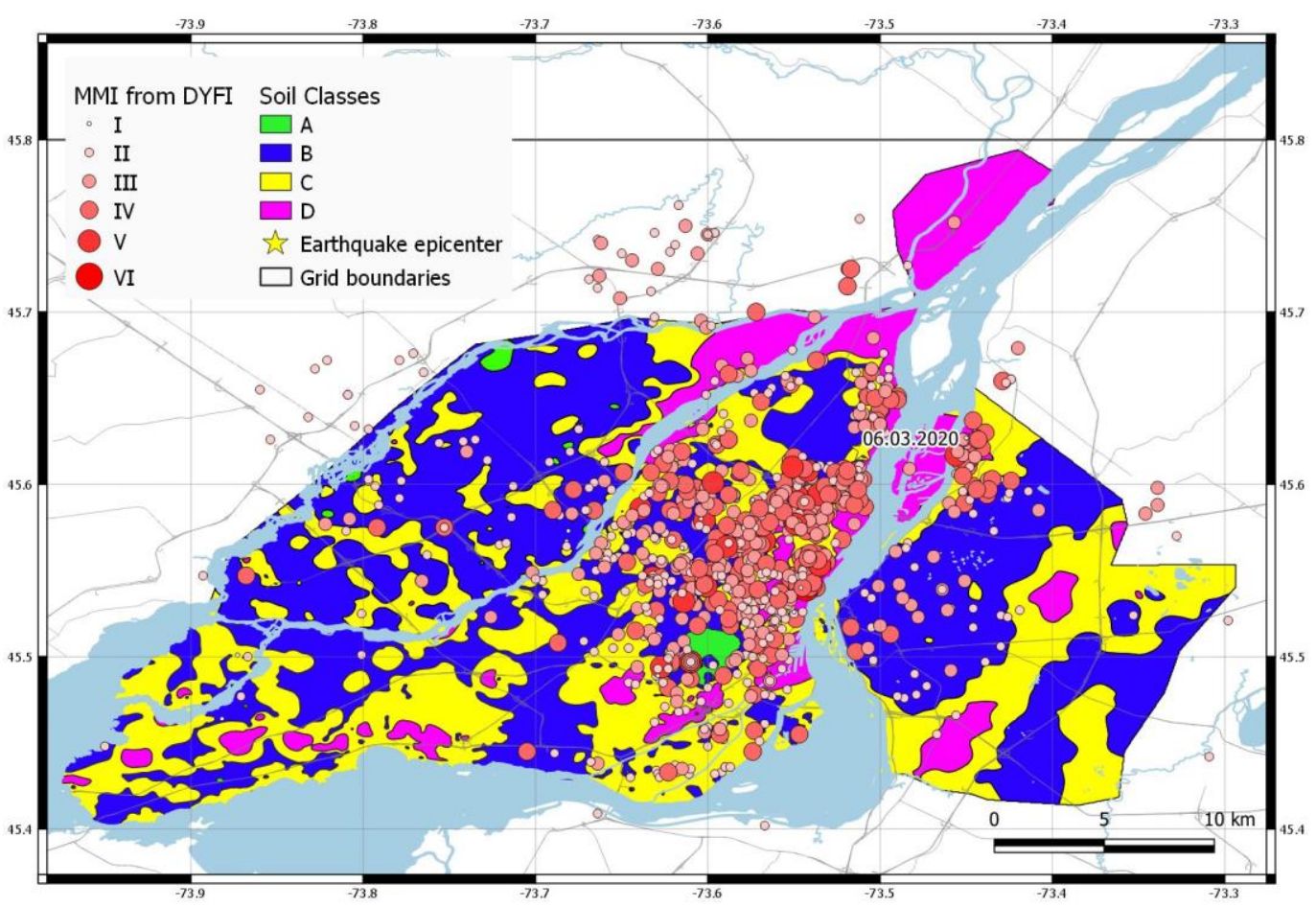

Figure 2. Distribution of the felt reports by levels of MMI for the March 6, 2020 earthquake. The epicenter is marked by a yellow star. Site classes in the seismic microzonation following the NBCC (2015)

The correlation between the soil classes and the distribution of MMI for the complete dataset is analyzed in Table 3. The percentage of data grouped by soil classes as given in the microzonation map is calculated by level of MMI. One can notice that the distribution of reports for soil class B decreases with MMI, is relatively constant for class $\mathrm{C}$ and increases for class D. The distribution of reports in soil class A region is insignificant due to the small number of reports.

Table 3. Distribution of DYFI data by MMI and soil class. The percentage by level of MMI is calculated for the complete dataset

\begin{tabular}{cccccr}
\hline \multirow{2}{*}{ MMI } & \multicolumn{6}{c}{ Percentage of reports by MMI level and soil class } & \multirow{2}{*}{ Number of reports } \\
\cline { 2 - 5 } & A & B & C & \multicolumn{1}{c}{ D } & 242 \\
I & 0.8 & 57.9 & 36.4 & 5.0 & 1976 \\
II & 0.0 & 57.0 & 34.7 & 8.3 & 2991 \\
III & 0.1 & 56.1 & 35.6 & 8.1 & 2506 \\
IV & 0.2 & 51.0 & 37.2 & 11.7 & 438 \\
V & 0.2 & 47.5 & 38.1 & 14.2 & 50 \\
VI & 0.0 & 46.0 & 34.0 & 20.0 & 8203 \\
\hline Number of reports & 10 & 4453 & 2956 & 784 &
\end{tabular}


In order to better correlate the felt reports and the proposed soil zonation for Montreal and surrounding municipalities, MMI data are grouped by cells of one by one $\mathrm{km}$ on a regular grid within the selected region. The number of reports and the average MMI in each cell is calculated. The maps of the Figures 3 and 4 show the average MMI for the complete dataset and the October 10, 2012 event, respectively. Only the cells with three or more reports are considered.

In general, cells with average MMI=IV are located in or close to regions with soil class D (purple colour). In some cases, the cells with this value are at the junction of two class D regions. In rare cases, they are located in class $\mathrm{C}$ or B regions. Cells with $\mathrm{MMI}=\mathrm{III}$ are mainly in regions with soil class B. One can find cells with $\mathrm{MMI}=\mathrm{III}$ in several regions with class D soil close to cells with MMI=IV. Cells with MMI=II are sparsely distributed within the grid mainly in class B regions. Only three MMI=II reports are located in class D regions. If the minimum number of reports by cells is increased, the general tendency described above is heightened. For example, if a minimum number of 5 reports is specified, cells with MMI=II in soil class D disappear.

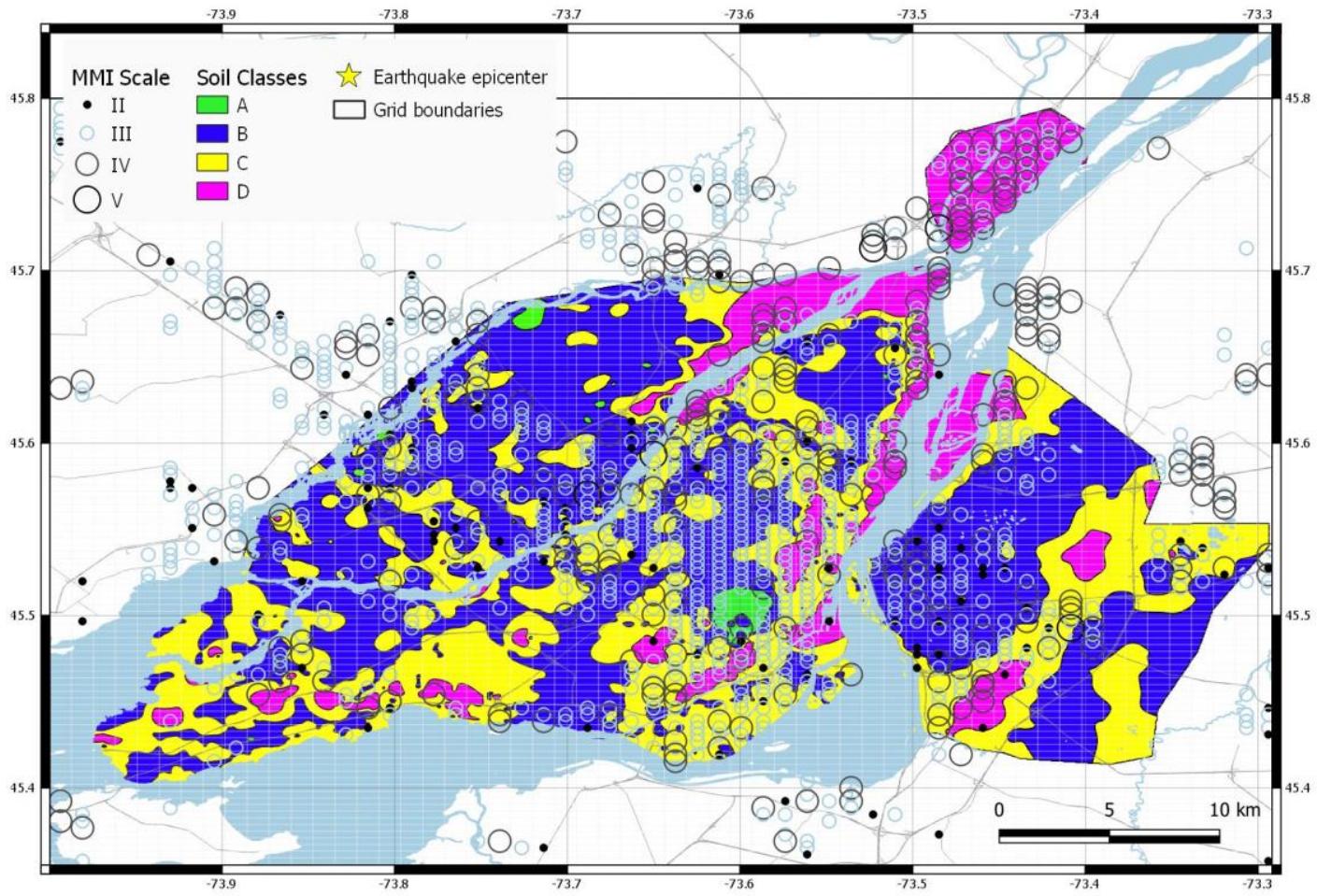

Figure 3. Distribution of the felt reports by average MMI for the complete dataset. Only cells with three or more reports are considered. The seismic zonation in terms of soil classes is used as background 


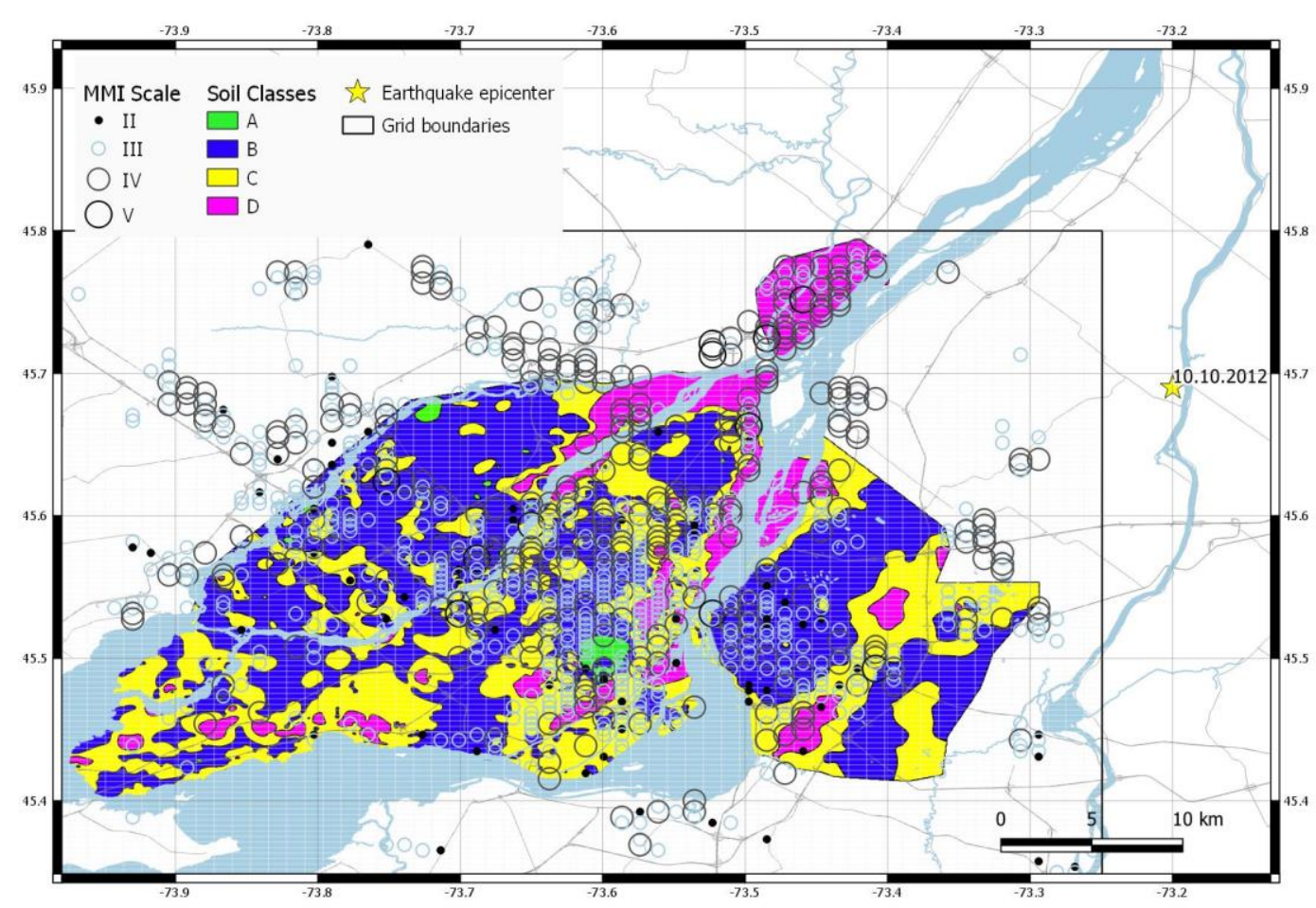

Figure 4. Distribution of the felt reports by average MMI for the October 10, 2012 earthquake. Same legend as Figure 3

Statistically speaking, when using the complete dataset, Table 4 shows that $41 \%$ of the cells in soil class D and $56 \%$ in soil class $\mathrm{C}$ have an average MMI=IV. A large majority of cells with soil class B $(77 \%)$ and $\mathrm{C}(70 \%)$ have an average MMI=III. The number of cells in soil class A and for MMI=V are not significant. A similar trend is found for the October 10, 2012 event (Table 5).

Table 4. Distribution of DYFI data by averaged MMI within the cells and soil class. The percentage by level of MMI is calculated for the overall dataset for cells with three or more reports

\begin{tabular}{crrrrr}
\hline \multirow{2}{*}{ MMI } & \multicolumn{6}{c}{ Percentage of reports by MMI level and soil class } & \multirow{2}{*}{ Number of cells } \\
\cline { 2 - 5 } & \multicolumn{1}{c}{ A } & B & \multicolumn{1}{c}{ C } & \multicolumn{1}{c}{ D } & 69 \\
II & 8.3 & 9.1 & 7.2 & 3.4 & 658 \\
III & 75.0 & 76.7 & 70.3 & 55.9 & 198 \\
IV & 16.7 & 13.9 & 21.8 & 40.7 & 4 \\
V & 0.0 & 0.3 & 0.8 & 0.0 & 929 \\
\hline Number of cells & 12 & 395 & 377 & 145 & \\
\hline
\end{tabular}

Table 5. Distribution of DYFI data by averaged MMI within the cells and soil class. The percentage by level of MMI is calculated for the October 102012 dataset for cells with three or more reports

\begin{tabular}{crrrrrr}
\hline \multirow{2}{*}{ MMI } & \multicolumn{3}{c}{ Percentage of reports by MMI level and soil class } & \multirow{2}{*}{ Number of cells } \\
\cline { 2 - 5 } & \multicolumn{1}{c}{ A } & B & & C & D & 42 \\
II & 18 & 7 & 5 & 3 & 465 \\
III & 55 & 67 & 65 & 48 & 224 \\
IV & 27 & 25 & 29 & 47 & 8 \\
V & 0 & 1 & 1 & 2 & 739 \\
\hline Number of cells & 11 & 314 & 286 & 128 & \\
\hline
\end{tabular}




\section{Discussion}

MMI data derived from DYFI reports after eight earthquakes largely felt in the region of Montreal are analyzed. More than 10,000 reports are used in a first stage to calculate the percentage by MMI value for each event. Independently of the magnitude, MMI are distributed between I-II, III and IV with 27, 38 and 30\%, respectively; the remaining reports are for MMI of V. There is no clear relationship between the hypocentral distance and the reported MMI both when considering or not the soil classification at the location of reports. Figure 5 illustrates this result for the October 2012 event which is the most recent and significantly large event.

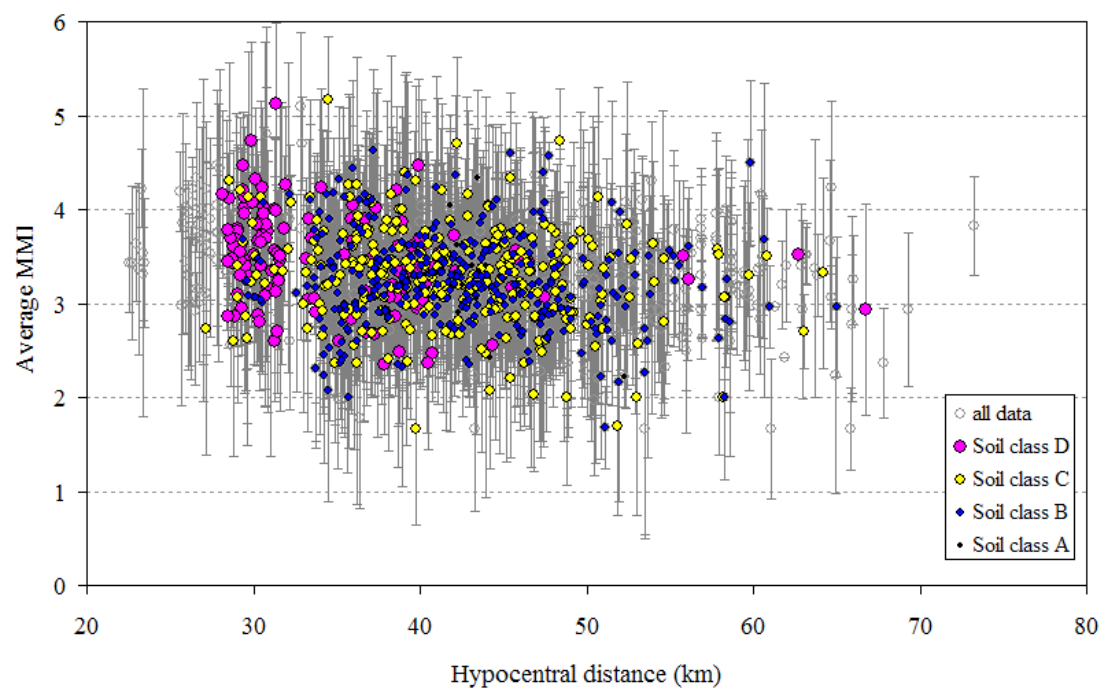

Figure 5. Average MMI versus hypocentral distance for the October 10, 2012 event. Data are grouped by cells with three or more reports and soil class. The vertical grey bars show the standard deviation around the mean MMI for each selected cell

In general, the percentage of reports for soil classes B and C is relatively constant for all levels of MMI but increases for class D with the increasing level of MMI. When the reports are grouped by cells of $1 \mathrm{~km}$ by $1 \mathrm{~km}$ and averaged, one can notice the relatively good correlation between the soil class and the level of MMI, the highest average MMI corresponding with regions with soil class D. High values of average MMI are also found in soil class C but often close to soil class D, which hints to the future use of this information to improve the seismic zonation, in particular in urbanized areas without any other information.

The extension of the seismic microzonation to the Greater Montreal area (Rosset et al., 2019) shows that the observed high average MMI in the NW part of the region is also well correlated with the presence of thick soft soil deposits of clay and sand.

\section{Acknowledgments}

The authors would like to acknowledge the financial support of the Ministère de la Sécurité Publique du Québec and the Discovery Grant from the Natural Sciences and Engineering Research Council of Canada.

\section{References}

Atkinson, G. M., \& Boore, D. M. (2006). Earthquake Ground-Motion Prediction Equations for Eastern North America. Bulletin of the Seismological Society of America, 96(6), 2181-2205. https://doi.org/10.1785/0120050245

Cajka, M. G., \& Halchuk, S. (1998). Collecting Intensity Data via the Internet: The Cap-Rouge, Québec Earthquake. Seismological Research Letters, 69, 585-587. https://doi.org/10.1785/gssrl.69.6.585

Cecić, I., \& Musson, R. (2004). Macroseismic Surveys in Theory and Practice. Natural Hazards, 31, 39-61. https://doi.org/10.1023/B:NHAZ.0000020255.00986.37

Drysdale, J., \& Cajka, M. (1989). Intensity Report of the November 25, 1988 Saguenay, Quebec Earthquake. GSC Open File Report \#3279.

Ghofrani, H., Atkinson, G. M., Chouinard, L., Rosset, P., \& Tiampo K. F. (2015). Scenario Shakemaps for Montreal. Can. J. Civ. Eng., 42, 463-476. https://doi.org/10.1139/cjce-2014-0496 
Haddon, R. A. W. (1992). Waveform modeling of strong motion data for the Saguenay earthquake of 25th November 1988. Bull. Seism. Soc. Am., 82, 720-754.

Halchuk, S. (2010). Intensity reports for the Val-des-Bois, Québec, earthquake of June 23, 2010. Canadian Hazards Information Service Internal Report 2010-3.1, 15 p. plus digital Appendix. https://doi.org/10.4095/287438. https://doi.org/10.4095/287438

NBCC. (2015). National Building Code of Canada, 14th Edition, Canadian Commission on Building and Fire Codes, National Research Council of Canada, Ottawa, Ontario, Canada.

Rosset, P., \& Chouinard, L. E. (2009). Characterization of site effects in Montreal, Canada. Natural Hazards, 48, 295-308. https://doi.org/10.1007/s11069-008-9263-1

Rosset, P., Bour-Belvaux, M., \& Chouinard, L. (2015). Estimation and Comparison of $\mathrm{V}_{\mathrm{s} 30}$; Microzonation Maps for Montreal Using Multiple Sources of Information. Bulletin of Earthquake Engineering, 13(8), 2225-2239. https://doi.org/10.1007/s10518-014-9716-8

Rosset, P., Kert, M., Youance, S., Nollet, M-J., \& Chouinard, L. (2019). Could Montreal residential buildings suffer important losses in case of major earthquakes?. Proceeding of the 12th Canadian Conference on Earthquake Engineering, Quebec, Canada, June 17-20. 7 p.

Wald, D. J., Quitoriano, V., Dengler, L. A., \& Dewey, J. W. (1999). Utilization of the Internet for Rapid Community Intensity Maps. Seismological Research Letters, 70(6), 680-697. https://doi.org/10.1785/gssrl.70.6.680

Yu, K., Rosset, P., \& Chouinard, L. E. (2016). Seismic Vulnerability Assessment for Montreal. Georisk, 10(2), 164-178. https://doi.org/10.1080/17499518.2015.1106562

\section{Copyrights}

Copyright for this article is retained by the author(s), with first publication rights granted to the journal.

This is an open-access article distributed under the terms and conditions of the Creative Commons Attribution license (http://creativecommons.org/licenses/by/4.0/). 